\title{
Evaluation of Serum Microfibrillar-associated Protein 4 in Patients with Erectile Dysfunction
}

N.W.Michael, E.M.Akal, A.Adel Al Fallah and M.I.Shaheen

Dermatology and Andrology Dept., Faculty of Medicine, Benha Univ., Benha, Egypt

E-Mail:dr.moh.shaheen@gmail.com

\begin{abstract}
Erectile dysfunction [ED] is persistent inability to achieve or maintain rigid penile erection sufficient for satisfactory sexual performance. It is a typical clinical element that influences basically men more seasoned than 40 years. Away from the psychogenic reasons for ED, numerous natural factors, for example, diabetes mellitus, hypertension, heftiness and smoking have been connected to the improvement of ED which is viewed as of vascular beginning in by far most of the patients. Microfibrillar-related protein 4 [MFAP4] is an extracellular network protein which legitimately ties to collagen, elastin and fibrillin. It is restricted to extracellular network protein strands in courses all through the body. MFAP4 has an immediate job in vascular occlusive redesigning with deferred neointimal development. The point of study is to assess MFAP4 in serum of patients with ED. We decided the degree of mfap4 in the serum by means of protein connected immunosorbent test [ELISA]. serum mfap4 levels in 50 ED patients were fundamentally higher than in 30 solid volunteers [p $>0.001$ ]. this outcome exhibited solid relationship among ED and serum level of mfap4, being expanded in ED.
\end{abstract}

\section{Introduction}

Microfibrillar-related protein 4 [MFAP4] is an extracellular lattice protein which legitimately ties to collagen, elastin and fibrillin in a calcium-subordinate way and co-limit with elastin microfibrils [5]. MFAP4 has been confined to flexible filaments in an assortment of versatile tissues, including lung and aorta. It adds to the versatile fiber get together as well as upkeep. MFAP4 co-restricts with fibrillin-1 in vivo in solid skin and stays bound to fibrillin-1 likewise in deteriorating flexible filaments [3]. This may demonstrate a job for MFAP4 in illnesses described by fibrillin corruption, for example, Marfan disorder where MFAP4 is up-directed in climbing aortic examples.

MFAP4 can be considered as a potential biomarker in neurotic conditions described by tissue fibrosis.

In fibrotic conditions, cell obtuseness toward ordinary administrative signs prompts exorbitant extracellular lattice affidavit. MFAP4 may fill in as a biomarker for liver cirrhosis, where MFAP4 serum focuses increment essentially with the movement of fibrosis improvement [4].

More significant levels of serum MFAP4 were found in patients with ongoing myocardial dead tissue contrasted with patients with stable coronary course atherosclerotic infection, and it was proposed that harm to the vein divider during late myocardial ischemia would cause the level of serum MFAP4 in these patients to increase [1].

\section{Methods}

Eighty people [50 patients with vasculogenic ED matured somewhere in the range of 45 and 64 with mean age [years] $53.22 \pm$ SD 5.84 and 30 clearly solid volunteers] were remembered for this investigation, performed at Dermatology and Andrology Department of Benha University Hospital between December 2018 and April 2020.

All subjects taking an interest in the investigation were approached to sign a composed assent before consideration. At that point, they were exposed to full history taking and clinical assessment.

Patients had gone through penile doppler ultrasound to survey the sort and level of vasculogenic ED. penile doppler ultrasound was performed with the patient in the prostrate position. The assessment was performed by a radiology master [AT] at Radiology Department, Benha University utilizing TOSHIBA ultrasound gadget with high-recurrence straight cluster transducers $7.5-9.0 \mathrm{MHz}$ test. Primer filtering with B-mode was done to limp penis then ED assessment was completed after intracavernous infusion of $1 \mathrm{ml}$ papaverine.

Blood examining of five $\mathrm{ml}$ of venous blood was gathered from every member under complete aseptic condition and put on a plain cylinder. The cylinder was left at room temperature for 30 minutes till coagulation and afterward centrifuged. The resultant serum was put away in aliquot at - 80oC until examine was finished.

Estimation of human MFAP4 was finished by utilizing human MFAP4 ELISA unit gave by SUNRED biotechnology Company, made in Shanghai, China. Parcel number: 202001

MFAP4 was added to monoclonal neutralizer Enzyme well which was pre-covered with Human MFAP4 monoclonal immune response. MFAP4 antibodies named with biotin were joined with Streptavidin-HRP to shape insusceptible complex. Brooding was completed and washing again was done to eliminate the uncombined protein. Chromogen Solution An and B were included, the shade of the fluid changed into the blue, and at the impact of corrosive, the shading at last got yellow. The chroma of shading and the centralization of human substance MFAP4 of test were emphatically related. Standerd weakening was performed by the maker directions. In clear wells, tests and MFAP4 counter acting agent named with biotin and Streptavidin-HRP were not included. Just chromogen arrangement $\mathrm{An}$ and $\mathrm{B}$, and stop arrangement were permitted. In standard wells, $50 \mu \mathrm{l}$ of standard and $50 \mu \mathrm{l}$ of Streptavidin-HRP were included. In test wells, $40 \mu$ of test was included and afterward both $10 \mu \mathrm{l}$ MFAP4 counter acting agent and $50 \mu \mathrm{l}$ of Streptavidin-HRP were included. At that point the fixing membrance was fixed, delicately shaked and brooded an hour at $37 \mathrm{oC}$. The membrance was taken out cautiously, the fluid was depleted and the rest of the water was shaked away. At that point, $50 \mu \mathrm{l}$ of chromogen arrangement An and $50 \mu \mathrm{l}$ of chromogen arrangement B were added to each well. Tenderly blended 
and brooded for 10 minutes at $37 \mathrm{oC}$ away from light. At that point $50 \mu \mathrm{l}$ of stop arrangement were added to each well to stop the response [the blue promptly changed to yellow]. To quantify conclusive outcome, clear all around was taken as zero and the optical thickness [OD] was estimated under $450 \mathrm{~nm}$ frequency which was done inside 15 minutes in the wake of including the stop arrangement.

Count of result:

Standard was taken as the flat scale, the OD esteem on the vertical scale, the standard bend was drawn on chart paper, the comparing fixation was found by the example bend, or the straight line relapse condition of the standard bend was determined with the standard focus and the OD esteem, as taken the example OD esteem in the condition, the example focus was determined, increased by the weakening element, the outcome was the example genuine fixation.

\section{Factual analysis}

The Statistical Analysis and introduction of information was directed utilizing Mean Standard deviation, Median and Inter-quartile extend [IQR] , MannWhitney's Test, Chi-Square test, Pearson's relationship coefficient and Logistic relapse by Statistical PC programs SPSS, form 11.5 for Windows [SPSS, Inc] and MedCalc, adaptation 18.2.1[MedCalc, Ostend, Belgium].

\section{Results}

Eighty persons were included in our study. Their age ranged from 45 to 64 years with a mean of age $53.22 \pm \mathrm{SD}$ 5.84. They were 50 patients with vasculogenic ED and 30 apparently healthy volunteers.

Table (1) Distribution of case group according to clinical findings.

\begin{tabular}{lcccc}
\hline & \multicolumn{4}{c}{ Case group [50] } \\
\cline { 2 - 5 } & Mean & $\mathbf{\pm S D}$ & Min & Max \\
\hline FBS mg/dl & 151.24 & 79.41 & 74.0 & 312.0 \\
SBP mm/Hg & 139.38 & 17.82 & 110.0 & 174.0 \\
DBP mm/Hg & 86.88 & 7.78 & 75.0 & 118.0 \\
IIEF & 11.48 & 4.38 & 5.0 & 20.0 \\
PSV m/s & 30.2 & 11.71 & 13.0 & 57.0 \\
EDV m/s & 8.16 & 5.27 & 0.4 & 19.0 \\
\hline
\end{tabular}

Fasting glucose [FBS] was estimated for the whole case bunch with mean FBS $151.24 \mathrm{mg} / \mathrm{dl} \pm$ SD $79.41 \mathrm{md} / \mathrm{dl}$.

Systolic pulse [SBP] was estimated for all case bunch with mean SBP $139.38 \mathrm{~mm} / \mathrm{Hg} \pm \mathrm{SD} 17.82 \mathrm{~mm} / \mathrm{Hg}$, while mean diastolic circulatory strain [DBP] was $86.88 \mathrm{~mm} / \mathrm{Hg}$ $\pm \mathrm{SD} 7.78 \mathrm{~mm} / \mathrm{Hg}$.
Universal record of erectile brokenness [IIEF] poll was filled by the patients with mean score $11.48 \pm$ SD 4.38 .

Pinnacle systolic speed [PSV] and end diatolic velosity [EDV], both estimated by penile doppler examining indicated mean PSV $30.2 \mathrm{~m} / \mathrm{s} \pm \mathrm{SD} 11.71 \mathrm{~m} / \mathrm{s}$ and mean EDV $8.16 \mathrm{~m} / \mathrm{s} \pm \mathrm{SD} 5.27 \mathrm{~m} / \mathrm{s}$.

Table (2) Comparison between case and control groups according to serum MFAP 4.

\begin{tabular}{|c|c|c|c|c|c|c|}
\hline & $\begin{array}{c}\text { Case } 8 \\
{[50]}\end{array}$ & & $\begin{array}{c}\text { Cont } \\
{[30]}\end{array}$ & oup & $\begin{array}{l}\text { Statistical } \\
\text { test }\end{array}$ & $p$ value \\
\hline & mean & $\pm \mathrm{SD}$ & mean & $\pm \mathrm{SD}$ & & \\
\hline SMFAP4 ng/dl & 18.45 & 7.96 & 5.38 & 2.24 & St $\mathrm{t}=8.77$ & $<0.001 * *$ \\
\hline
\end{tabular}

Mean serum level of MFAP4 for cases was significant difference between patients and controls $18.45 \mathrm{ng} / \mathrm{dl} \pm \mathrm{SD} 7.96 \mathrm{ng} / \mathrm{dl}$, and for controls was $5.38 \mathrm{ng} / \mathrm{dl}$ regarding serum level of MFAP4 with $\mathrm{p}$ value $<0.001$.

$\pm \mathrm{SD} 2.24 \mathrm{ng} / \mathrm{dl}$. This study showed that there was a

Table (3) Validity of SMFAP 4 in prediction of ED.

\begin{tabular}{|c|c|c|c|c|c|c|}
\hline \multirow[t]{2}{*}{ SMFAP 4} & \multicolumn{2}{|c|}{$\begin{array}{c}\text { Case group } \\
{[50]}\end{array}$} & \multicolumn{2}{|c|}{ Control group [30] } & \multirow[t]{2}{*}{$\begin{array}{c}\text { Statistical } \\
\text { test [x2] }\end{array}$} & \multirow[t]{2}{*}{ p value } \\
\hline & No & $\%$ & No & $\%$ & & \\
\hline$\geq 6.93$ & 49 & 98 & 6 & 20 & 53.1 & $<0.001 * *$ \\
\hline$<6.93$ & 1 & 2 & 24 & 80 & & \\
\hline $\mathrm{AUC}[95 \% \mathrm{CI}]$ & \multicolumn{6}{|c|}{$0.977[0.952-1.0]$} \\
\hline Cut-off point & \multicolumn{6}{|c|}{6.93} \\
\hline Sensitivity & \multicolumn{6}{|c|}{98.0} \\
\hline Specificity & \multicolumn{6}{|c|}{80.0} \\
\hline PPV & \multicolumn{6}{|c|}{89.1} \\
\hline NPV & \multicolumn{6}{|c|}{96.0} \\
\hline Accuracy & \multicolumn{6}{|c|}{91.3} \\
\hline
\end{tabular}


The study also showed that there was a significant positive correlation between serum level of MFAP4 and [age, fasting blood sugar, diastolic blood pressure and smoking].

There was a significant negative correlation between serum level of MFAP4 and IIEF.

There was no significant correlation between serum level of MFAP4 and [systolic blood pressure, peak systolic velocity and end diastolic velocity].

\section{Discussion}

This study was led to assess serum level of MFAP4 in patients with vasculogenic ED and its job in vascular flexibility.

This investigation included 80 people [50 patients with vasculogenic ED and 30 evidently sound volunteers as a control]. Their age went from 45 to 64 years with a mean old enough 53.22 \pm SD 5.84.

This concurred with [6] in regards to the maturing related ED. They recommended that the maturing related cycle that prompts ED starts from the get-go throughout everyday life. They meant that maturing related vascular issue happen because of a brokenness and additionally loss of the corporal smooth muscle cells [SMC], the principle constituent of the corporal sinusoids. As one gets more established, these SMC proceed to debase and vanish. When roughly $15 \%$ of these cells have been affected, the outcome is a powerlessness of the corporal tissue to hold as well as keep the blood from "spilling" out of the corporal sinusoids into the foundational veins.

Among the fifty patients remembered for this examination, 32 patients had fundamental hypertension. With mean SBP $139.38 \mathrm{~mm} / \mathrm{Hg} \pm \mathrm{SD} 17.82 \mathrm{~mm} / \mathrm{Hg}$ and mean diastolic circulatory strain [DBP] was $86.88 \mathrm{~mm} / \mathrm{Hg}$ \pm SD $7.78 \mathrm{~mm} / \mathrm{Hg}$. These outcomes uphold the relationship among hypertension and erectile brokenness.

Our outcomes concur with [7], who explored the aortic flexible boundaries in patients with ED. Both aortic distensibility list and aortic strain file were essentially lower in the patients with ED than in the solid men. The aftereffects of their examination proposed a nearby relationship among ED and vascular sicknesses at the degree of the endothelial respectability and vascular versatility.

This additionally went with [8]. They dissected the connection among hypertension and erectile brokenness. The patients remembered for their investigation exhibited a similar arteriosclerosis inside their penile cavernosal bodies and other fringe arterioles, prompting high vascular obstruction and lacking blood vessel inflow, which may clarify why hypertension is a typical danger factor related with ED. Their meta-investigation upheld that hypertension is related with an expanded danger of ED.

Wondimeneh et al., [9] found that smokers who smoked 20 cigarettes or all the more every day have a higher danger of ED; this impact stayed critical in the wake of modifying for expected confounders. Smokers who smoked 20 cigarettes or all the more every day have a higher danger of ED affirm past exploration across various nations.
This is predictable with the consequences of our investigation in which 34 out of the fifty patients were smokers.

Fasting glucose estimated for patients in this examination demonstrated that the mean FBS was $151.24 \mathrm{mg} / \mathrm{dl}$ with standerd deviation $\pm 79.41 \mathrm{md} / \mathrm{dl}$. This backings diabetes milletus as a danger factor for ED in concurrence with [10].

R.M. Carrillo-Larco et al., [10], inspected applicable investigations on ED in individuals with diabetes milletus living in Africa and found that long span of DM, age $>40$ years, testosterone lack, fringe neuropathy, not being engaged with physical exercise, and fringe vascular sickness were altogether connected with expanded danger of ED among diabetic patients.

Y. Kouidrat et al., [11], detailed that predominance of ED was higher in men with Type 2 diabetes than in any case solid men. Their discoveries recommended that screening for ED in men before screening for Type 2 diabetes could improve the odds of accurately recognizing those at high danger of Type 2 diabetes. The potential instruments partner ED and diabetes include: [1] hormonal lack [men with diabetes have lower testosterone levels]; [2] endothelial brokenness and shortage of nitric oxide at the penis flow level, identified with oxidative pressure, progressed glycation finished results and endothelins; and [3] impeded blood water system to the vasa nervosum at the penis [cavernous nerve] level.

Completed a meta-examination to survey the commonness of erectile brokenness in diabetes, incorporating a huge volume of worldwide writing [including 145 investigations and 88577 male members with diabetes]. They demonstrated a general commonness of erectile brokenness of $59.1 \%$ in men with diabetes. The condition was essentially higher in those with Type 2 diabetes contrasted and Type 1 diabetes, and in more seasoned members. Men with diabetes will in general create erectile brokenness $10-15$ years sooner than those without diabetes. Indeed, erectile brokenness is the third most successive inconvenience of diabetes that influences the personal satisfaction and it is regularly demonstrative of hidden vasculopathy speaking to a predictor of more serious cardiovascular disorders.

\section{Conclusion}

This investigation was the main examination to assess level of MFAP4 in the serum of patients with vasculogenic ED. There was critical connection between's serum level of MFAP4 and vasculogenic ED, levels of MFAP4 were higher in ED patients than sound volunteers. Additionally there was negative connection between's degrees of MFAP4 and IIEF.

This outcome harmonizes with information accessible in writing about mfap4 as a potential biomarker in neurotic conditions portrayed by tissue fibrosis.

\section{References}

[1] H. Wulf-Johansson, S. Lock Johansson, A. Schlosser, Localization of microfibrillar-associated protein 4 [MFAP4] in human tissues: clinical 
evaluation of serum MFAP4 and its association with various cardiovascular conditions. PLoS ONE, Vol. 8(12), PP.e82243,2013.

[2] Schlosser, B.Pilecki, L.E.Hemstra. MFAP4 promotes vascular smooth muscle migration, proliferation and accelerates neointima formation. Arterioscler Thromb Vasc Biol , Vol. 36(1) ,PP.122-33,2016.

[3] S.G.Saekmose,

B.Mossner, P.B.ChristensenMicrofibrillar-associated protein 4: a potential biomarker for screening for liver fibrosis. PLoS ONE,Vol.10 (10), PP. e0140418,2015.

[4] T.Thomsen, A.Schlosser, U. Holmskov. Ficolins and FIBCD1: soluble and membrane bound pattern recognition molecules with acetyl group selectivity,Vol.48,PP. 369-381,2011.

[5] G.Monica Ferrini1, F.Nestor Gonzalez-Cadavid, Jacob Rajfer. Aging related erectile dysfunction-potential mechanism to halt or delay its onset. Transl Androl Urol ,Vol.6(1), PP.20-27,2017.

[6] Cevdet Kaya, Mehmet Ergelen, Abdullah Ilktac, Impaired Elasticity of Aorta in Patients with Erectile Dysfunction. UROLOGY,Vol. 70,PP.558-562,2007.

[7] Xiao-yan Wang, Wei Huang, Yong Zhang, Relation between hypertension and erectile dysfunction: a metaanalysis of cross-section studies. International Journal of Impotence Research, 22 May, Vol.30(3), PP.141-146,2018

[8] J.R. Kovac, C. Labbate, R. Ramasamy, Effects of cigarette smoking on erectile dysfunction. Andrologia. Dec, Vol. 47(10), PP. 1087-1092,2015.

[9] Wondimeneh Shibabaw Shiferaw, Tadesse Yirga Akalu, Pammla Margaret Petrucka, Risk factors of erectile dysfunction among diabetes patients in Africa: A systematic review and meta-analysis. Journal of Clinical \& Translational Endocrinology, Vol. 21, PP.100-232,2020.

[10] R.M. Carrillo-Larco, A.C. Luza-Duenas, M.UrdanigaHung, Short Report: Epidemiology Diagnosis of erectile dysfunction can be used to improve screening for Type 2 diabetes mellitus. Diabet. Med, Vol.35,PP. 1538-1543, 2018.

[11] Y. Kouidrat, D. Pizzo, T. Cosco, High prevalence of erectile dysfunction in diabetes: a systematic review and meta-analysis of 145 studies. Diabet. Med, Vol. 34, PP. 1185-1192,2017. 